\title{
Analysis of Concrete by Adding Cement with Crushed Fluorescent Lamp Powder
}

\author{
Thavasumony $\mathrm{D}^{\# 1}$, Shalin Prince N.R ${ }^{\# 2}$, Ragin $\mathrm{T}^{\# 3}$, Sheeba $\mathrm{D}^{\# 4}$ \\ $\#^{l}$ Lecturer, Department of Civil Engineering in Ambo University, Midalakkadu, India. \\ ${ }^{\# 2}$ Lecturer, Department of Built Environment Engineering in Muscat College Sultanate of Oman, Mulagumoodu, India. \\ \#3 Assistant Professor, Department of Civil Engineering in Maria College of Engineering and Technology, Attoor, India. \\ ${ }^{\# 4}$ Assistant Professor, Department of Civil Engineering in Udaya School of Engineering, Nagercoil, India.
}

\begin{abstract}
Now a day's Building demand is constantly increasing $\&$ the capital cost of the construction of a building to is escalating, The demand for construction material is also increasing, at the same time the cost of the construction material is also increasing, To overcome these type of problems are want to found the new composition with low cost, Our ultimate aim of the project is: To introduce Fluorescent lamp powder as fine aggregate as one of the new material into the concrete. To find out the mix ratio by using Fluorescent lamp powder as fine aggregate in concrete to achieve the target mean strength. To solve the environmental problem of the huge amount of disposal Waste Fluorescent lamp. Moreover disposal of solid waste is the major problem in recent scenario. This project deals with the study of concrete by partial adding of fine aggregate with the Fluorescent lamp powder. Trial mixes are performed to achieve a concrete of M20 grade where natural fine aggregate is substituted by weight with crushed Fluorescent lamp powder at the rates varying from $2,4,6,8$ and 10percentages. The properties of binder, aggregates and Fluorescent lamp powder are also studied. The tests are conducted after proper curing on 7 days and 28 days and the test results are furnished in tabular form as well as in graphical form.
\end{abstract}

Keywords - Fluorescent Lamp, Flexural, Dicalcium Silicate, Tricalcium Silicate, Abrasion, Granule.

\section{INTRODUCTION}

Presently all the structures are constructed using concrete as a major construction material. Now we are using river sand for concrete structures which leads to the unavailability and hence an increase in cost of the river sand than in olden days. In developing countries like India where abundant solid wastes are discharged, these wastes can be used as potential materials or replacement materials in the construction industry. This will have the double advantage of reduction in the cost of construction material and also a means of disposal of waste. It is at this time the above approach is logical, worthy and attributable. The new and alternative building construction materials developed using solid wastes have sample scope for introducing new building components that will reduce to an extent the cost of building materials.

Our ultimate aim of the project is:

- To introduce Fluorescent lamp powder as fine aggregate as one of the new material into the concrete.
- To find out the mix ratio by using Fluorescent lamp powder as fine aggregate in concrete to achieve the target mean strength.

- To solve the environmental problem of disposal of huge amount of Waste Fluorescent lamp.

\section{A. Description of Fluorescent Lamp Powder:}

A fluorescent lamp or fluorescent tube is a gas-discharge lamp that uses electricity to excite mercury vapor. A typical fluorescent lamp is composed of a sealed glass tube filled with argon gas at a low pressure, as well as a low partial pressure of mercury vapor, thus the tube is a partial vacuum.1,2 The inside of the tube is coated with a powder composed of various phosphor compounds.

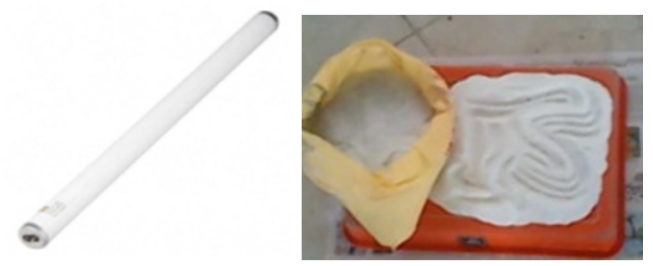

Fig 1 Fluorescent Lamp and crushed Fluorescent Lamp Powder

\section{B. Description of Ferrous Sulphate Powder:}

Ferrous Sulfate is a light blue or light yellow powder or granule, soluble in water and glycerol, insoluble in ethanol, and easy oxidized in air. It is used in agriculture, it used for plant fertilizer, soil amendments, pesticides, etc. Concrete etching, staining and sealing is a great way to turn a floor into a beautiful finished product. The chemical formula is $\mathrm{FeSO}_{4} \cdot 7 \mathrm{H}_{2} \mathrm{O}$.

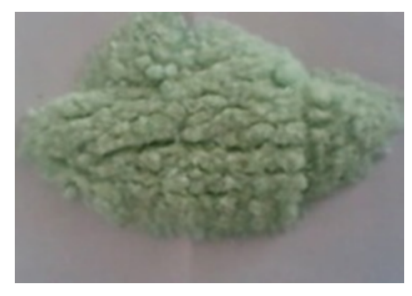

Fig 2 Ferrous Sulphate Powder 


\section{Chemical composition of Portland cement:}

The raw material in the manufacture of Portland cement consists of lime, silica, alumina and iron oxide. These compounds interact with one another in the kiln to form a series of more complex products. The relative proportions of these compounds for influencing the various properties of cement, rate of cooling and fineness of grinding of compounds are usually regarded as a major constituent of cement. They are listed in table together with their abbreviated symbols.

TABLE 1

COMPOSITION OF PORTLAND CEMENT COMPOUNDS

\begin{tabular}{|c|c|c|}
\hline $\begin{array}{c}\text { Name of } \\
\text { compound }\end{array}$ & $\begin{array}{c}\text { Normal } \\
\text { Percentage } \\
\text { of OPC }\end{array}$ & $\begin{array}{c}\text { Average } \\
\text { Percentage of } \\
\text { OPC }\end{array}$ \\
\hline Alumina of clay & $5 \%$ & $3-8 \%$ \\
\hline Slica & $22 \%$ & $17-25 \%$ \\
\hline Lime & $62 \%$ & $60-67 \%$ \\
\hline Iron Oxide & $3 \%$ & $0.5-6 \%$ \\
\hline Magnesia & $2 \%$ & $0.1-4 \%$ \\
\hline Sulpher Trioxide & $1 \%$ & $1-3 \%$ \\
\hline Alkalies & $1 \%$ & $0.2-1 \%$ \\
\hline Calciam Sulphate & $4 \%$ & $3-5 \%$ \\
\hline
\end{tabular}

The calculation of potential composition of Portland Cement is based on the work of R.M Bogue and others and is often referred to as Bogues Composition". Sometimes these Bogues compounds are known as Alite Berite, Celite, Felite respectively, made by the crystallography Studies by Le Chatelier and Tornebohn. Hydration of Cement: Hydrous cement does not bind fine and coarse aggregate. It acquires cohesive adhesive property only when mixed with water. The chemical reaction that takes places between cement and water is known as hydration of Cement. Mechanism Of Hydration: The manner in which Silica fume increases strength of concrete is still unknown. Some evidence shows that concrete added with silica fume undergoes an increase in strength without increase in strength of cement paste. This supports the fact that silica fume strengthen concrete by increasing bond strength between cement aggregate. Tricalcium Silicate and Dicalcium Silicate on Hydration give rise to Calcium Silicate Hydrate and Calcium Hydroxide. During the course of hydration of Tricalcium Silicate and Dicalcium Silicate with water, Calcium silicate hydrates abbreviated as $\mathrm{C}-\mathrm{S}-\mathrm{H}$ and Calcium hydroxide are formed. Calcium Silicate hydrates is the most important product. It is that determines the good properties of concrete.

$2\left(\mathrm{CaO} . \mathrm{SiO}_{2}\right)+6 \mathrm{H}_{2} \mathrm{O} \rightarrow 3 \mathrm{CaO} .2 \mathrm{SiO} 2.3 \mathrm{H} 2 \mathrm{O}+3 \mathrm{Ca}(\mathrm{OH})_{2}$ $2\left(2 \mathrm{CaO} \cdot \mathrm{SiO}_{2}\right)+\mathrm{H}_{2} \mathrm{O} \rightarrow 3 \mathrm{CaO} \cdot 2 \mathrm{SiO}_{2} \cdot 3 \mathrm{H}_{2} \mathrm{O}+\mathrm{Ca}(\mathrm{OH})_{2}$

It can be seen that $\mathrm{C}_{3} \mathrm{~S}$ produces a comparatively lesser quantity of Calcium Silicate hydrates and more quantity of $\mathrm{Ca}(\mathrm{OH})_{2}$ than that formed in the hydration of $\mathrm{C}_{3} \mathrm{~S} . \mathrm{Ca}(\mathrm{OH})_{2}$ is not a desired product in concrete mass. It is soluble in water and gets leached out making the concrete porous, particularly in hydraulic structures. Due to addition of silica fume to concrete, the strength of concrete may be improved by two mechanism, ie. as a super pozzalona and as a filler.

\section{LITERATURE REVIEW}

Throughout the world, concrete is used for all types of construction. Hence, it has been properly labeled as the backbone to the infrastructure development of a nation. Currently, our country is taking major initiatives to improve and develop its infrastructure by constructing express highways, power projects and industrial structures to emerge as a major economic power. To meet out this rapid infrastructure development a huge quantity of concrete is required. Unfortunately, India is not self sufficient in the production of cement and availability of natural sand is also decreasing making the construction activities very costlier. Hence, currently, the entire construction industry is in search of suitable and effective materials and methods that would considerably minimize the use of concrete ingredients and ultimately reduce the construction cost. Few of such products have already been identified like Rice Husk Ash (RHA), Fly Ash, Silica Fumes, Egg shell powder etc.

\section{A. The Use of Sheet Glass Powder as Fine Aggregate Replacement in Concrete:}

The experimental study was carried out by substituting Natural fine aggregate in weight by Sheet Glass Powder at rates varying from 10, 20,30, 40 and 50 percentages. From the test results it has been found that the optimum replacement level in fine aggregate with SGP is $10 \%$ by M. Mageswari and Dr.B.Vidivelli.

\section{B. Recycling Steel Mill Scale as Fine Aggregate in Cement Mortars:}

This paper presents preliminary findings of a study that investigates the potential for recycling steel mill scale into concrete from a local steel manufacturing company that generates high quantities reaching almost 7000 tons/year. Several mixes were tried out with $0,20,40,50,70$ and $100 \%$ replacement by steel mill scale. The main conclusion of his observation was that when steel mill scale replaces $40 \%$ of the sand in concrete it gives the highest increase in compressive strength compared to the other by Saud Al-Otaibi Associate Research Scientist, Kuwait Institute for Scientific Research.

C. Utilization of Olive Husk as a Replacement of Fine Aggregate in Portland cement Concrete Mixes for NonStructural Uses:

This research aims at partially solving the environmental problem of olive oil wastes (husk $\&$ ash) by utilizing this waste 
in non-structural concrete mixes. Different percentages of replacement as $0,25,50,75,100$ percentage of olive husk or ash were used in for concrete grades such as PCC150, PCC200, PCC250, PCC300, and PCC450. It is difficult to deal with Portland cement concrete having more than $25 \%$ by volume of replacement of olive husk. At $75 \%$ and $100 \%$ replacement by olive husk, Portland cement concrete loses its inherent structure by Iyad Jameel Ahmad Bani Odi.

As many researchers have been carried out with the waste materials found in abundance in the locality, our project deals with the utilization of Waste Tube Lights obtained in large amount from residential buildings, hostel buildings, hotels buildings, etc,. Presently they are used as poultry feed and if it is being used in the production of concrete it may be a good solution to both the requirement of a newer material in construction industry and disposal of a solid waste to have a good environment.

\section{EXPERIMENTAL INVESTIGATIONS}

This chapter deals with the various tests conducted to study the properties of the binder, coarse aggregate and fine aggregate for the purpose of obtaining the desired mix design. These tests were carried out as per Bureau of Indian Standards for testing.

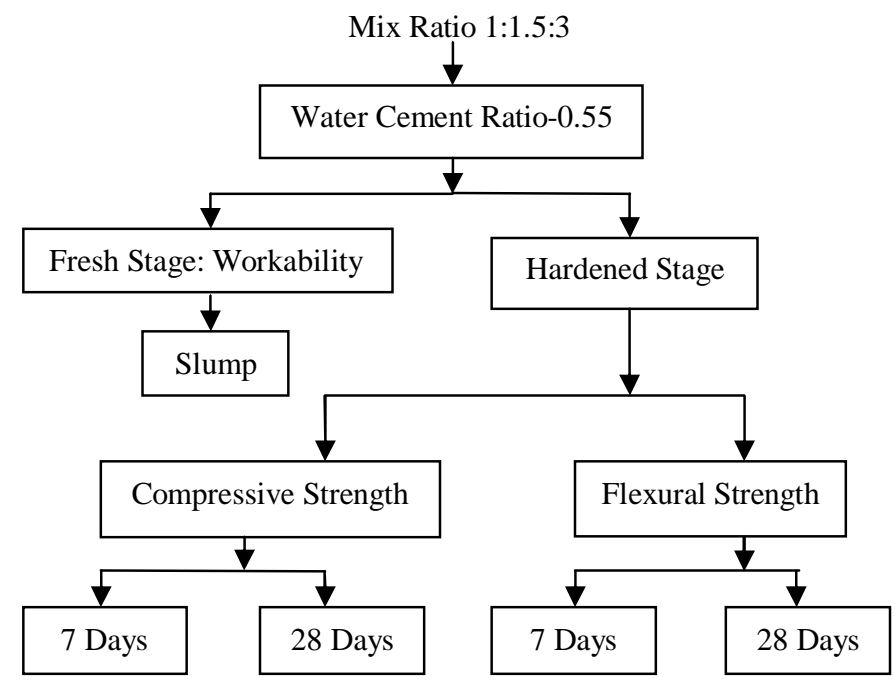

\section{A. Tests on cement:}

Cement is the most important ingredient in concrete. One of the important criteria for the selection of cement is its ability to produce improved microstructure in concrete. Conventional cement concrete (CCC), the effect of characteristics of cement on water demand is more noticeable. Some of the important factors which play a vital role in the selection of cement are compressive strength at various ages, fineness, heat of hydration, alkali content, tri calcium aluminates $\left(\mathrm{C}_{3} \mathrm{~A}\right)$ content, tri calcium silicate $\left(\mathrm{C}_{3} \mathrm{~S}\right)$ content, di calcium silicate $\left(\mathrm{C}_{2} \mathrm{~S}\right)$ content etc. It is also necessary to ensure compatibility of the chemical and mineral admixtures with cement.

- Standard Consistency Test: $20 \%$

- Initial Setting Time: 60 minutes

- $\quad$ Final Setting Time: 450 minutes

B. Properties of Coarse Aggregates:

The following tests are performed on coarse aggregate.

- Sieve Analysis: Fineness modulus of coarse aggregate $20 \mathrm{~mm} \& 12 \mathrm{~mm}$ is $7.75 \& 6.7$.

Fineness modulus $=\frac{\text { sum of cumulative } \% \text { og aggregateretained to } 150 \mathrm{~mm}}{100}$

- Crushing Test: Crushing value of coarse aggregate $=21$

The aggregate crushing value $=(\mathrm{B} / \mathrm{A}) \times 100$

Where, $\mathrm{B}=$ the fraction passing the sieve is weighted. $\mathrm{A}=$ the weight of the sampled contained in the Cylinder measure is taken.

- Impact Test: Impact value of coarse aggregate $=18$ Aggregate impact Value $=\mathrm{B} / \mathrm{Ax} 100$

- $\quad$ Specific Gravity Test: gravity of aggregate $=2.71$ $\mathrm{S} . \mathrm{G}=\left(\mathrm{W}_{2}-\mathrm{W}_{1}\right) /\left(\mathrm{W}_{2}-\mathrm{W}_{1}\right)-\left(\mathrm{W}_{3}-\mathrm{W}_{4}\right)$

- Abrasion Test: Abrasion value of coarse aggregate= 23

- Water Absorption Test: Water Absorption Value for 20 $\& 12 \mathrm{~mm}$ aggregate are $0.27 \%$ and $0.3 \%$.

TABLE 2

PROPERTIES OF COARSE AGGREGATE

\begin{tabular}{|c|c|c|c|}
\hline $\begin{array}{l}\text { Sl. } \\
\text { No }\end{array}$ & \multicolumn{2}{|c|}{ Properties } & Coarse Aggregate \\
\hline 1 & \multicolumn{2}{|c|}{ Specific Gravity } & 2.71 \\
\hline 2 & \multicolumn{2}{|c|}{ Crushing Value } & 21 \\
\hline 3 & \multicolumn{2}{|c|}{ Impact Value } & 18 \\
\hline 4 & \multicolumn{2}{|c|}{ Abrasion Value } & 23 \\
\hline \multirow[t]{2}{*}{5} & \multirow[t]{2}{*}{ Fineness Modulus } & $20 \mathrm{~mm}$ & 7.75 \\
\hline & & $12 \mathrm{~mm}$ & 6.7 \\
\hline \multirow[t]{2}{*}{6} & \multirow[t]{2}{*}{ Water Absorption } & $20 \mathrm{~mm}$ & $0.27 \%$ \\
\hline & & $12 \mathrm{~mm}$ & $0.3 \%$ \\
\hline
\end{tabular}

C. Properties of Fine Aggregate:

The following tests are performed on fine aggregate.

- Sieve Analysis

- Specific Gravity Test

- Bulking effect of fine aggregate

- Water Absorption Test 
TABLE 3

PROPERTIES OF FINE AGGREGATE

\begin{tabular}{|c|c|c|}
\hline Sl. No & Properties & Sand \\
\hline 1. & Specific Gravity & 2.59 \\
\hline 2. & Bulking effect & $36.8 \%$ \\
\hline 3. & Water absorption & 0.5 \\
\hline 4. & Bulkage at a water Content of & $4 \%$ \\
\hline
\end{tabular}

D. Water:

Water is an important ingredient of concrete as it actively participates in the chemical reactions with cement to form the hydration product, calcium-silicate-hydrate $(\mathrm{C}-\mathrm{S}-\mathrm{H})$ gel. The strength of cement concrete depends mainly from the binding action of the hydrated cement paste gel.

\section{E. Tests on Fresh Concrete:}

Above Specimens are taken. The weighed ingredients are mixed by hand mixing. The test specimens are cast in cast - iron steel moulds of size $150 \mathrm{~mm} \times 150 \mathrm{~mm} \times 150 \mathrm{~mm}$. The inside of the moulds are applied with oil to facilitate the easy removal of specimens. The concrete was placed in the moulds in three layers of equal thickness with proper tamping. The specimens of size $150 \mathrm{~mm} \times 150 \mathrm{~mm} \times 150 \mathrm{~mm}$ cubes are cast and then compacted on a table vibrator. The tests are carried out at 7,14 and 28 days in compression testing machine and the load carrying capacity are noted.

The following tests are performed on fresh concrete.

- Slump Cone Test

- Compaction Factor Test

Compaction Factor $=$ Weight of partially compacted concrete / Weight of fully compacted concrete

\section{F. Tests on Hardened Concrete:}

The following tests are conducted on hardened concrete.

- Cube Compressive Strength Test

- Flexural Strength Test

\section{RESUlts AND Discussion}

\section{A. Compressive Strength:}

The test results for compressive strength of concrete on 7 days and 28 days with Ferrous Sulphate powder $2 \%$ constant \& Fluorescent lamp powder $2 \%-16 \%$ are added with tabulated as follows. From the 28 days compressive strength tests results, it is observed that the variation in compressive strength is from $42.9 \mathrm{~N} / \mathrm{mm}^{2}$ to $23.704 \mathrm{~N} / \mathrm{mm}^{2}$ and up to $12 \%$ added of cement by Fluorescent lamp powder has achieved a compressive strength which is more than $99 \%$ of the target mean strength and achieved a $20 \%$ excess of the target mean strength.
TABLE 4

COMPRESSIVE STRENGTH FOR 7 DAYS

\begin{tabular}{|r|c|c|c|c|}
\hline $\begin{array}{c}\text { SI. } \\
\text { No }\end{array}$ & Cube Size & $\begin{array}{c}\text { Fluorescent } \\
\text { Lamp } \\
\text { Powder }\end{array}$ & $\begin{array}{c}\text { Ferrous } \\
\text { Sulphate } \\
\text { Powder }\end{array}$ & $\begin{array}{c}\text { Average } \\
\text { Compressive } \\
\text { Strength at } \\
\text { 7days } \\
\text { N/mm }\end{array}$ \\
\hline 1. & $\begin{array}{l}150 \mathrm{mmx} 150 \\
\mathrm{mmx} 150 \mathrm{~mm}\end{array}$ & - & - & 4.8 \\
\hline 2. & $\begin{array}{l}150 \mathrm{mmx} 150 \\
\mathrm{mmx150mm}\end{array}$ & $2 \%$ & $2 \%$ & 17.7 \\
\hline 3. & $\begin{array}{c}150 \mathrm{mmx} 150 \\
\mathrm{mmx} 150 \mathrm{~mm}\end{array}$ & $4 \%$ & $2 \%$ & 20 \\
\hline 4. & $\begin{array}{l}150 \mathrm{mmx} 150 \\
\mathrm{mmx} 150 \mathrm{~mm}\end{array}$ & $6 \%$ & $2 \%$ & 26.67 \\
\hline 5. & $\begin{array}{l}150 \mathrm{mmx} 150 \\
\mathrm{mmx} 150 \mathrm{~mm}\end{array}$ & $8 \%$ & $2 \%$ & 31.11 \\
\hline 6. & $\begin{array}{l}150 \mathrm{mmx} 150 \\
\mathrm{mmx} 150 \mathrm{~mm}\end{array}$ & $10 \%$ & $2 \%$ & 33.33 \\
\hline 7. & $\begin{array}{l}150 \mathrm{mmx} 150 \\
\mathrm{mmx} 150 \mathrm{~mm}\end{array}$ & $12 \%$ & $2 \%$ & 34.15 \\
\hline 8. & $\begin{array}{l}150 \mathrm{mmx} 150 \\
\mathrm{mmx} 150 \mathrm{~mm}\end{array}$ & $14 \%$ & $2 \%$ & 34.1 \\
\hline 9. & $\begin{array}{l}150 \mathrm{mmx} 150 \\
\mathrm{mmx} 150 \mathrm{~mm}\end{array}$ & $16 \%$ & $2 \%$ & 32.85 \\
\hline
\end{tabular}

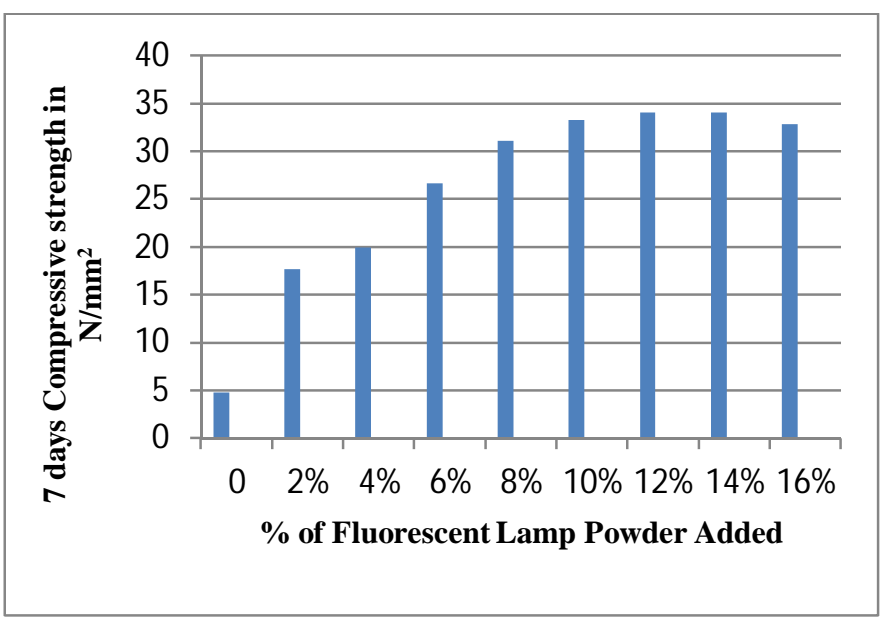

Fig. 3 - 7 days Compressive Strength Vs \% of Fluorescent Lamp Powder

TABLE 5

COMPRESSIVE STRENGTH FOR 28 DAYS

\begin{tabular}{|c|c|c|l|c|}
\hline $\begin{array}{l}\text { SI. } \\
\text { No }\end{array}$ & Cube Size & $\begin{array}{c}\text { Fluorescent } \\
\text { Lamp } \\
\text { Powder }\end{array}$ & $\begin{array}{l}\text { Ferrous } \\
\text { Sulphate } \\
\text { Powder }\end{array}$ & $\begin{array}{c}\text { Average } \\
\text { Compressive } \\
\text { Strength at } \\
\text { 7days, } \\
\text { N/mm }\end{array}$ \\
\hline 1. & $\begin{array}{c}150 \mathrm{mmx} 150 \mathrm{~m} \\
\mathrm{mx} 150 \mathrm{~mm}\end{array}$ & - & - & 13.037 \\
\hline
\end{tabular}




\begin{tabular}{|c|c|c|c|c|}
\hline 2. & $\begin{array}{c}150 \mathrm{mmx} 150 \mathrm{~m} \\
\mathrm{mx} 150 \mathrm{~mm}\end{array}$ & $2 \%$ & $2 \%$ & 23.704 \\
\hline 3. & $\begin{array}{c}150 \mathrm{mmx} 150 \mathrm{~m} \\
\mathrm{mx} 150 \mathrm{~mm}\end{array}$ & $4 \%$ & $2 \%$ & 26.667 \\
\hline 4. & $\begin{array}{c}150 \mathrm{mmx} 150 \mathrm{~m} \\
\mathrm{mx} 150 \mathrm{~mm}\end{array}$ & $6 \%$ & $2 \%$ & 28.148 \\
\hline 5. & $\begin{array}{c}150 \mathrm{mmx} 150 \mathrm{~m} \\
\mathrm{mx} 150 \mathrm{~mm}\end{array}$ & $8 \%$ & $2 \%$ & 35.556 \\
\hline 6. & $\begin{array}{l}150 \mathrm{mmx} 150 \mathrm{~m} \\
\mathrm{mx} 150 \mathrm{~mm}\end{array}$ & $10 \%$ & $2 \%$ & 41.481 \\
\hline 7. & $\begin{array}{l}150 \mathrm{mmx} 150 \mathrm{~m} \\
\mathrm{mx} 150 \mathrm{~mm}\end{array}$ & $12 \%$ & $2 \%$ & 42.325 \\
\hline 8. & $\begin{array}{c}150 \mathrm{mmx} 150 \mathrm{~m} \\
\mathrm{mx} 150 \mathrm{~mm}\end{array}$ & $14 \%$ & $2 \%$ & 42.9 \\
\hline 9. & $\begin{array}{c}150 \mathrm{mmx} 150 \mathrm{~m} \\
\mathrm{mx} 150 \mathrm{~mm}\end{array}$ & $16 \%$ & $2 \%$ & 39.985 \\
\hline
\end{tabular}

FLEXURAL STRENGTH FOR 7 DAYS

\begin{tabular}{|c|c|c|c|c|}
\hline $\begin{array}{l}\text { SI. } \\
\text { No }\end{array}$ & Beam Size & $\begin{array}{c}\text { Fluorescent } \\
\text { Lamp } \\
\text { Powder }\end{array}$ & $\begin{array}{l}\text { Ferrous } \\
\text { Sulphate } \\
\text { Powder }\end{array}$ & $\begin{array}{c}\text { Average } \\
\text { Flexural } \\
\text { Strength at } \\
\text { 7days, } \\
\text { N/mm } \\
\end{array}$ \\
\hline 1. & $\begin{array}{l}500 \mathrm{mmx} 100 \\
\mathrm{mmx} 100 \mathrm{~mm}\end{array}$ & - & - & 1.64 \\
\hline 2. & $\begin{array}{l}500 \mathrm{mmx} 100 \\
\mathrm{mmx} 100 \mathrm{~mm}\end{array}$ & $2 \%$ & $2 \%$ & 2.354 \\
\hline 3. & $\begin{array}{l}500 \mathrm{mmx} 100 \\
\mathrm{mmx} 100 \mathrm{~mm}\end{array}$ & $4 \%$ & $2 \%$ & 2.44 \\
\hline 4. & $\begin{array}{l}500 \mathrm{mmx} 100 \\
\mathrm{mmx} 100 \mathrm{~mm}\end{array}$ & $6 \%$ & $2 \%$ & 2.6 \\
\hline 5. & $\begin{array}{l}500 \mathrm{mmx} 100 \\
\mathrm{mmx} 100 \mathrm{~mm}\end{array}$ & $8 \%$ & $2 \%$ & 2.7 \\
\hline 6. & $\begin{array}{l}500 \mathrm{mmx} 100 \\
\mathrm{mmx} 100 \mathrm{~mm}\end{array}$ & $10 \%$ & $2 \%$ & 2.74 \\
\hline 7. & $\begin{array}{l}500 \mathrm{mmx} 100 \\
\mathrm{mmx} 100 \mathrm{~mm}\end{array}$ & $12 \%$ & $2 \%$ & 2.75 \\
\hline 8. & $\begin{array}{l}500 \mathrm{mmx} 100 \\
\mathrm{mmx} 100 \mathrm{~mm}\end{array}$ & $14 \%$ & $2 \%$ & 2.74 \\
\hline 9. & $\begin{array}{l}500 \mathrm{mmx} 100 \\
\mathrm{mmx} 100 \mathrm{~mm}\end{array}$ & $16 \%$ & $2 \%$ & 2.69 \\
\hline
\end{tabular}

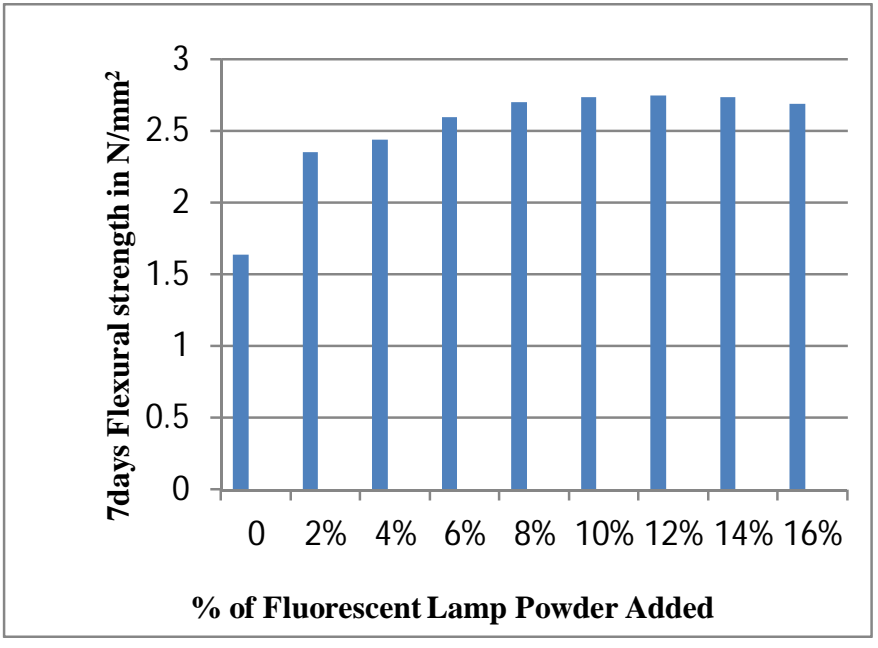
respectively. The tests results were shown in tabular and the graphical form also. From the above tests results, it is found that up to $12 \%$ added of cement by Fluorescent lamp powder has achieved a permissible value.

Fig. 4 -28 days Compressive Strength Vs \% of Fluorescent Lamp Powder from $2.75 \mathrm{~N} / \mathrm{mm}^{2}$ to $2.354 \mathrm{~N} / \mathrm{mm}^{2}$ and $3.4 \mathrm{~N} / \mathrm{mm}^{2}$ to $2.4 \mathrm{~N} / \mathrm{mm}^{2}$

\section{B. Flexural Strength:}

The test results Flexural strength of concrete on 7days and 28 days with Ferrous Sulphate powder $2 \%$ constant \& Fluorescent lamp powder 2\% - 16\% are added with tabulated as follows. From the 7 days and 28 days of flexural strength tests results, it is observed that the variation in flexural strength is
Fig. 5 -7 days Flexural Strength Vs \% of Fluorescent Lamp Powder 
TABLE 7

FLEXURAL STRENGTH FOR 28 DAYS

\begin{tabular}{|c|c|c|c|c|}
\hline $\begin{array}{l}\text { SI. } \\
\text { No }\end{array}$ & Beam Size & $\begin{array}{c}\text { Fluorescent } \\
\text { Lamp } \\
\text { Powder }\end{array}$ & $\begin{array}{l}\text { Ferrous } \\
\text { Sulphate } \\
\text { Powder }\end{array}$ & $\begin{array}{c}\text { Average } \\
\text { Flexural } \\
\text { Strength at } \\
\text { 7days , } \\
\text { N/mm }\end{array}$ \\
\hline 1. & $\begin{array}{l}500 \mathrm{~mm} \times 100 \\
\mathrm{~mm} \times 100 \mathrm{~mm}\end{array}$ & - & - & 2.000 \\
\hline 2. & $\begin{array}{l}500 \mathrm{~mm} \times 100 \\
\mathrm{~mm} \times 100 \mathrm{~mm}\end{array}$ & $2 \%$ & $2 \%$ & 2.400 \\
\hline 3. & $\begin{array}{l}500 \mathrm{~mm} \times 100 \\
\mathrm{~mm} \times 100 \mathrm{~mm}\end{array}$ & $4 \%$ & $2 \%$ & 2.500 \\
\hline 4. & $\begin{array}{l}500 \mathrm{~mm} \times 100 \\
\mathrm{~mm} \times 100 \mathrm{~mm}\end{array}$ & $6 \%$ & $2 \%$ & 2.540 \\
\hline 5. & $\begin{array}{l}500 \mathrm{~mm} \times 100 \\
\mathrm{~mm} \times 100 \mathrm{~mm}\end{array}$ & $8 \%$ & $2 \%$ & 3 \\
\hline 6. & $\begin{array}{l}500 \mathrm{~mm} \times 100 \\
\mathrm{~mm} \times 100 \mathrm{~mm}\end{array}$ & $10 \%$ & $2 \%$ & 3.200 \\
\hline 7. & $\begin{array}{l}500 \mathrm{~mm} \times 100 \\
\mathrm{~mm} \times 100 \mathrm{~mm}\end{array}$ & $12 \%$ & $2 \%$ & 3.4 \\
\hline 8. & $\begin{array}{l}500 \mathrm{~mm} \times 100 \\
\mathrm{~mm} \times 100 \mathrm{~mm}\end{array}$ & $14 \%$ & $2 \%$ & 3.35 \\
\hline 9. & $\begin{array}{l}500 \mathrm{~mm} \times 100 \\
\mathrm{~mm} \times 100 \mathrm{~mm}\end{array}$ & $16 \%$ & $2 \%$ & 3.2 \\
\hline
\end{tabular}

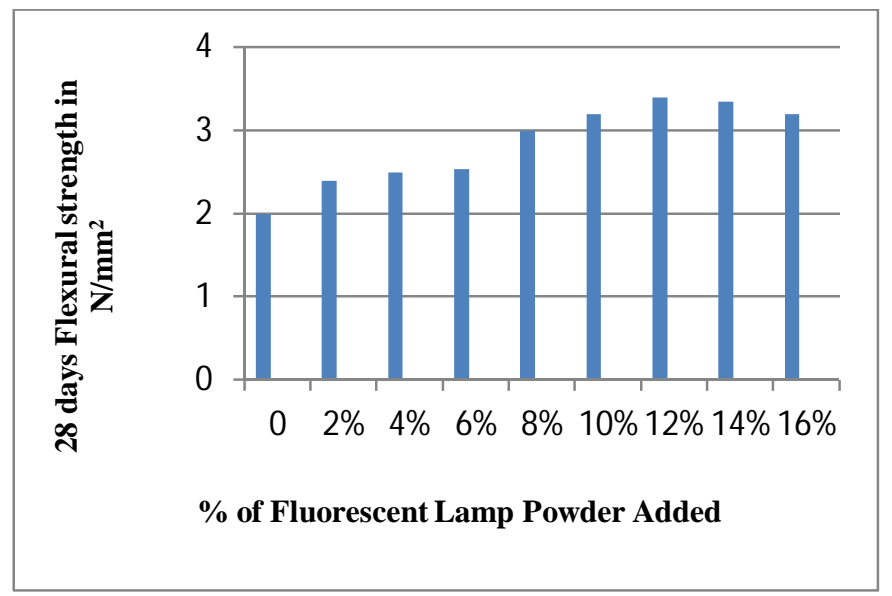

Fig. 6- 28 days Flexural Strength Vs \% of Fluorescent Lamp Powder

\section{CONCLUSIONS}

From the experimental studies on the behaviour of concrete specimens using partial adding of cement by crushed Fluorescent lamp Powder it is concluded that

- $10 \%$ of the cement used in concrete production can be effectively added with Fluorescent lamp Powder.

- Usage of Fluorescent lamp Powder in concrete will not only be economical but also satisfies all the requirements of a good concrete.
- This also proves to be a good solution for the disposal of a solid waste as it is recycled without affecting the environment.

\section{REFERENCES}

[1] Shetty, M.S, (2002), "concrete Technology", Theory and Practice, Chand \& Company Ltd. New Delhi.

[2] IS 456-2000 " Code of practice plain and Reinforced Concrete", $\left(4^{\text {th }}\right.$ Revision)

[3] IS 10262-1982 " Recommended guide lines for concrete Mix Design"

[4] IS 516-1959 "Methods of test for Strength of Concrete"

[5] SP : 23 Hand book on Concrete Mixes.

[6] Shao Y., Lefort T., Moras S., Rodriguez D. Studies on concrete containing ground waste glass. Cement and Concrete Research: 30, 2000, pp. 91-100.

[7] EKO 2007, EKO-UNIA, Szklo jako surowiec wtorny, Raport prepared by Ecological Association, 2007.

[8] Siddique R. Waste materials and by-products in concrete. Springer,

[9] 2008, pp. 413.

[10] Sakhmenko G., Korjakins A., Bumanis G. Bore-Silicate Glass Waste of Lamp as a Micro-Filler for Concrete // Scientific

[11] Byars EA, Morales-Hernandez B, Zhu HY, Waste glasses as concrete aggregate and pozzolan, Concrete, 38(1), 2004, pp.41-44

[12] Bazant ZP, Zi G, Meyer C, Fracture mechanics of ARS in concretes with waste glass particles of different sizes, J Eng Mech, 126, 2000, pp.226-232. 